\title{
Landscape as a Ritual Object: Exploring Some Thoughts on Organized Space in the Great Bend Region in Southwestern Arkansas
}

Duncan P. McKinnon

University of Central Arkansas

Follow this and additional works at: https://scholarworks.sfasu.edu/ita

Part of the American Material Culture Commons, Archaeological Anthropology Commons, Environmental Studies Commons, Other American Studies Commons, Other Arts and Humanities Commons, Other History of Art, Architecture, and Archaeology Commons, and the United States History Commons

Tell us how this article helped you.

This Article is brought to you for free and open access by the Center for Regional Heritage Research at SFA ScholarWorks. It has been accepted for inclusion in Index of Texas Archaeology: Open Access Gray Literature from the Lone Star State by an authorized editor of SFA ScholarWorks. For more information, please contact cdsscholarworks@sfasu.edu. 


\section{Landscape as a Ritual Object: Exploring Some Thoughts on Organized Space in the Great Bend Region in Southwestern Arkansas}

\section{Creative Commons License}

\section{(c) (i) (8)}

This work is licensed under a Creative Commons Attribution-NonCommercial 4.0 International License 


\title{
LANDSCAPE AS A RITUAL OBJECT: \\ Exploring Some Thoughts on ORganized Space in the Great BEND REgion in SOUTHWESTERn ARKANSAS
}

\section{Duncan P. McKinnon}

\begin{abstract}
This paper proposes a testable model to explore humanistic interpretations of landscapes that have been deliberately arranged, organized, executed, and modified based upon a particular suite of highly integrated political, social, economic, and ideological rules and aspirations about space. This model examines the landscape as a ritual object, embedded with cosmological meaning, purpose, and vision. Using data from archaeogeophysical surveys, excavations, and surface collections, some thoughts on organized space in the Great Bend region in southwestern Arkansas are presented with respect to regional site distributions, cardinal directionality, and intra-site spatial relationships as they exist across the cultural landscape.
\end{abstract}

\section{Introduction}

The exploration of cultural principles expressed in constructed landscapes has been examined at numerous archaeological sites throughout the world in both 'historic' and 'prehistoric' temporal contexts (Ashmore and Knapp 1999; David and Thomas 2008; Thompson 1995; Wilkinson 2003). In eastern North America, many might already be familiar with various landscape-centric expressions of organized space at numerous Archaic, Woodland, and Mississippian period centers. Locations such as Watson Brake (Saunders et al. 2005), Poverty Point (Gibson 2001), Newark (Lepper 2004), Cahokia (Dalan et al. 2003; Emerson 1997), and Moundville (Knight 1998) are but five of the hundreds, if not thousands, of constructed landscapes that were deliberately arranged, organized, executed, and modified based upon a particular suite of highly integrated political, social, economic, and ideological rules and aspirations about space (see Feld and Basso 1996; Hirch and O’Hanlon 1995; Low and Lawrence-Zúñiga 2003).

Within the Caddo Homeland of southeast Oklahoma, southwest Arkansas, northwest Louisiana, and northeast Texas (see Kniffen et al. 1987; Krieger 1946; McKinnon 2011a; Newcomb 1961; Perttula 1992, 2009a, 2012a, 2012b; Webb and Gregory 1986), similar analyses of cultural principles embedded within landscapes have contributed toward more humanistic interpretations of landscapes, their various spatial components, and possible ideological meanings encoded within (see Kay et al. 1989; Perttula 2009b; Sabo 2008, 2012; Sabo and Sabo 2005). These investigations reveal that architectural forms and associated settlement distribution across the Caddo landscape are likely linked to cosmological canons, derived but regionally adapted, from ideological and symbolic principles as part of the larger Southeastern Ceremonial Complex (see Brown 1976; Galloway 1989; Howard 1968; Knight 1986; Knight et al. 2001; Waring and Holder 1945).

This paper explores spatial-cultural components that define a specific Caddo landscape in southwest Arkansas to infer associations and linkages tied to ideological and symbolic principles. In other words, landscape, as a cultural space that contains integrated functional and symbolic components, is treated herein as a ritual object - an object that is embedded with cosmological meaning, purpose, and vision and is fully integrated into the daily lives and functions of the occupants (Anschuetz et al. 2001; Kornfeld and Osborn 
2003; Robb 1998). These connected functional and symbolic components are often manifest at a multitude of integrated spatial resolutions and relationships, such as broad-scale regional level distributions of natural and culturally constructed features (Blitz and Lorenz 2006; Girard 2012; Lockhart 2012; Marrinan and White 2007; Perttula 2009b; Pollack 2004; Rafferty and Peacock 2008; Rees and Livingood 2007; Sabo 2008; Vogel 2012), an intra-site or intra-organizational scale reflected as the deliberate spatial orientation of special use structures, activity areas, and delineated spaces (Bailey 1995; Brown 2012; King et al. 2011; Knight 1998; Perttula and Rogers 2007; Sabo 2012; Walker and McKinnon 2012), and micro or small scale resolutions at the individual household or structure level and the examination of interior space (see Deetz 1982; Gasco 1992; Jackson et al. 2012; Schambach 1996; Pluckhahn 2010; Trubitt 2009; Wilk and Rathje 1982).

In this paper, two of these resolutions (broad-scale regional and intra-site organization) are examined using data gathered from archaeogeophysical surveys, archaeological excavations, and surface collections. Through these examinations, a model of organized space is presented in order to explore how cultural principles might be expressed along the Great Bend landscape in southwest Arkansas.

\section{Exploring Caddo Landscapes as Ritual Objects}

Similar to elaborately crafted Mississippian period objects, considered ritual in use and embedded with meaning that is symbolically linked to ideology, performance, and ceremony, landscape can also be considered a ritual object, embedded with similar meanings and linked to similar social concepts (see Freidel and Schele 1988; Matthews 2004; Cobb 2003). From a humanistic geography perspective, landscape is "contested both as an actual place and as the figurative site of an ongoing socio-political discourse concerning the relations between community, self, and place" (Olwig 2001:94). But how do we, as archaeologists, ethnohistorians, geographers, and the like, use spatial data, in all its various tabular forms, to provide insight into humanistic concepts of landscape and ritual meaning? One way to approach this is through an examination of settlement patterning to "search for land use patterns and strive to find driving forces behind land use differences to come up with land use classifications that are meaningful in socio-economic and cultural terms" (Moran 2008:100). More so, the examination of patterns in land use and associated "spatial ordering at comparable levels of resolution may thus reveal new insights concerning the use of cosmological principles in pre-contact times and the manner in which these principles persisted or changed over time" (Sabo 2012:446).

Various considerations of Caddo settlement patterning across a landscape have largely been influenced by a map of an Upper Nasoni village located along the Red River created by an anonymous cartographer of the Domingo Terán de los Rios expedition between 1691 and 1692 (see Hatcher 1932; Swanton 1942; Wedel 1978). Known colloquially as the Terán map, the map is one of the few ethnohistorical sources documenting a synchronic view of a spatial layout of a Caddo community and provides an historically based model of the organization of a Red River Caddo community and constituent farmsteads, as documented in 1691 (Schambach 1982). The location of the Nasoni community has been identified as the Hatchel-Mitchell-Moores (41BW3) site complex located in Bowie County, Texas (Perttula 2005; Walker and McKinnon 2012; Wedel 1978). Specifically, the platform mound at the Hatchel site is considered the temple mound depicted in the Terán map (Perttula 2005; Wedel 1978). In addition to the large mound situated on the western edge of the community, a few of the dispersed farmsteads documented in the map have been archaeologically identified and recorded along this portion of the Red River (Perttula 2005; Walker and McKinnon 2012; Walker and Perttula 2007). The large temple mound contains only three constructed components in the immediate vicinity - the mound itself, a templo or temple on the mound summit, and an open-air structure at the mound base. Two delineated farmsteads, each separated by a vegetation boundary or fence, are situated directly northeast and east of the mound. Further to the east of the Hatchel mound, and centrally located in the community, is the home of the Caddi or community leader (see Bolton 1987; Griffith 1954; Swanton 1942). 
The Terán map has been suggested by Sabo (2012) to represent a cosmogram that is embedded in the organization of space at the Hatchel-Mitchell-Moores community. In his analysis, Sabo (2012) suggests that the mound and temple on the western fringes of the Nasoni community functioned as both a physical and symbolic "gateway" where visitors entered the community and were welcomed with various eating, smoking, and cleansing ceremonies and rituals (see Sabo 1995). These rituals served to communicate and connect individuals with both the human realm (This World or Middle World) and the spirit realm (Upper World or Above World) (see Reilly 2004). In terms of spatial patterning, Sabo suggests that the Nasoni community layout represents a "hierarchically-ordered community" with the temple mound, home to the priestly Xinesi and serving as the central point for the maintenance of social relationships with the Upper World, and the Caddi residence centrally located within the community and serving as the central point for the maintenance of social relationships with members of the This World community. These two centers, and the symbolic constituents they support, were 'connected' through the kindling of a sacred fire or 'axis mundi' that was continually reaffirmed through ritual. This sacred fire was subsequently 'shared' with the individual fires within the community farmsteads, thus maintaining symbolic and community cohesion within a framework of overarching cosmological beliefs and community relationships.

\section{The Great Bend Ritual Landscape}

Within the Great Bend region of southwest Arkansas, an examination of the archaeological landscape at a regional scale offers some initial observations that can be considered with regard to settlement distribution and cosmological principles, keeping in mind the potential for site biases related to location-based survey projects and incomplete data gathering throughout the years.

The Great Bend region is fairly centralized within the Caddo Archaeological Area, an area delineated based on archaeological and ethnohistorical data, and the Trans-Mississippi South, a distinct biogeographical area situated between the Lower Mississippi Valley and the southern Plains (see Perttula 1992; Schambach 1982). With agriculturally productive soil deposits, diverse ecology, and navigable waterways, the Great Bend region is host to numerous prehistoric and historic archaeological sites. Principal among them are the many sites left by the ancestors of the Caddo Indians that lived in this area as early as ca. A.D. 900 (see Schambach 1982; Perttula 1992, 2012).

The Great Bend region is a large area with numerous sites spread along the Red River that extend, more or less, at least as far west as the Hatchel-Mitchel-Moores community and at least as far south as the Belcher (16CD13) site Caddo Parish, Louisiana (Webb 1959). As part of this study, a specific area of the larger Great Bend region was selected in order to explore cultural distributions and examples of the organization of space (Figure 1). The area of interest in this study is an approximatley 600 square kilometer area bounded to the east and west by the Red River uplands. The large Battle Mound (3LA1) site is centrally situated.

Using the Automated Management of Archeological Site Data in Arkansas (AMASDA) database, sites $(n=97)$ and their recorded attributes were examined for spatial patterns that might reflect cultural principles in the area of interest. Three "groups" or "clusters" of sites are recognizable with the meandering Red River bisecting the river valley on a north-south alignment. As this discussion is a model of landscape organization of space to be explored and tested further, contemporaneity between sites is not specifically addressed in this paper. Such a discussion will require testing in the field to gather additional (or in many cases, some) temporal data. 


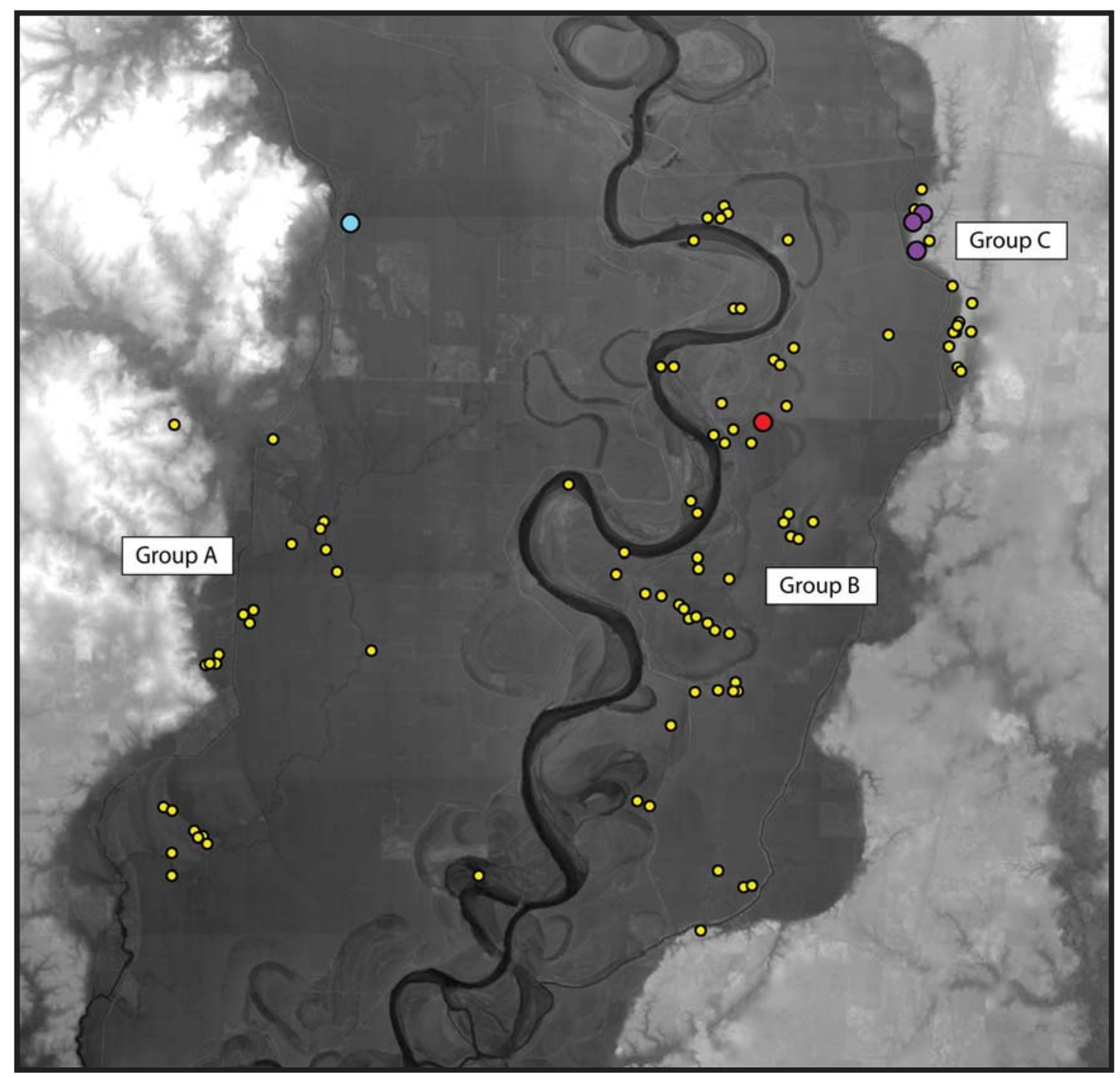

Figure 1. Distribution of recorded sites in the Great Bend region study area. Blue circle in Group A represents the Hensley Mound (3MI123) site. Red circle in Group B represents the Battle Mound (3LA1) site. Purple circles in Group C represent the Spirit Lake Farm Mound (3LA239), Red Hill Mound (3LA21), and Field Bayou Mound (3LA22) sites.

Roughly six kilometers west of the Red River and located along McKinney Bayou (Group A) are several sites ( $n=24)$ situated along the western edge of the Red River floodplain (see Figure 1). Calculating the presence or absence of individual artifact types at all sites in Group A, lithic debris has been recorded at $97 \%$ of the sites, ceramic sherds at $29 \%$ of the sites, and faunal remains at $0.04 \%$ of the sites (Table 1 ). At a single site (3MI92), faunal remains were collected. The high occurrence of lithic material and low percentage of ceramics along the McKinney Bayou landscape suggests the possibility that these sites represent examples of specific use activities, such as hunting or resource procurement. There are no extant mounds recorded among these sites, although the Hensley Mound (3MI123) site deviates from this pattern. Unfortunately, the mound was plowed down in the early 1970s and much of the land leveled for agriculture. There are no collections associated with Hensley Mound site. The location of what is left of the Hensley Mound is approximately $6 \mathrm{~km}$ (3.72 miles) to the north of the Group A cluster and is also situated along McKinney Bayou. 
Table 1. Great Bend Study Area Sites and Associated Artifacts recorded in AMASDA.

\begin{tabular}{|c|c|c|c|c|c|c|c|}
\hline Sites & Location & Mound & Lithic & Ceramic & \begin{tabular}{c|} 
Human \\
Remains
\end{tabular} & Faunal & AMASDA \# \\
\hline $3 \mathrm{MI0123}$ & GROUP A & 1 & 0 & 0 & 0 & 0 & 1085 \\
\hline $3 \mathrm{MI0177}$ & GROUP A & 0 & 1 & 0 & 0 & 0 & 1121 \\
\hline $3 \mathrm{MI0113}$ & GROUP A & 0 & 1 & 0 & 0 & 0 & 501 \\
\hline $3 \mathrm{MI0127}$ & GROUP A & 0 & 1 & 1 & 0 & 0 & $501 ; 1085$ \\
\hline $3 \mathrm{MI0112}$ & GROUP A & 0 & 1 & 0 & 0 & 0 & 501 \\
\hline $3 \mathrm{MI0111}$ & GROUP A & 0 & 1 & 1 & 0 & 0 & 501 \\
\hline $3 \mathrm{MI0109}$ & GROUP A & 0 & 1 & 0 & 0 & 0 & 501 \\
\hline $3 \mathrm{MI0063}$ & GROUP A & 0 & 1 & 0 & 0 & 0 & 501 \\
\hline $3 \mathrm{MI0080}$ & GROUP A & 0 & 1 & 1 & 0 & 0 & 501 \\
\hline $3 \mathrm{MI0070}$ & GROUP A & 0 & 1 & 1 & 0 & 0 & 501 \\
\hline $3 \mathrm{MI0069}$ & GROUP A & 0 & 1 & 1 & 0 & 0 & 501 \\
\hline $3 \mathrm{MI0211}$ & GROUP A & 0 & 1 & 1 & 0 & 0 & 501 \\
\hline $3 \mathrm{MI0209}$ & GROUP A & 0 & 1 & 0 & 0 & 0 & 501 \\
\hline $3 \mathrm{MI0} 212$ & GROUP A & 0 & 1 & 1 & 0 & 0 & 501 \\
\hline $3 \mathrm{MI0210}$ & GROUP A & 0 & 1 & 0 & 0 & 0 & 501 \\
\hline $3 \mathrm{MI0441}$ & GROUP A & 0 & 1 & 0 & 0 & 0 & 6338 \\
\hline $3 \mathrm{MI0097}$ & GROUP A & 0 & 1 & 0 & 0 & 0 & 501 \\
\hline $3 \mathrm{MI0096}$ & GROUP A & 0 & 1 & 0 & 0 & 0 & 501 \\
\hline $3 \mathrm{MI0095}$ & GROUP A & 0 & 1 & 0 & 0 & 0 & 501 \\
\hline $3 \mathrm{MI0094}$ & GROUP A & 0 & 1 & 0 & 0 & 0 & 501 \\
\hline $3 \mathrm{MI0092}$ & GROUP A & 0 & 1 & 0 & 0 & 1 & 501 \\
\hline $3 \mathrm{MI0091}$ & GROUP A & 0 & 1 & 0 & 0 & 0 & 501 \\
\hline $3 \mathrm{MI0093}$ & GROUP A & 0 & 1 & 0 & 0 & 0 & 501 \\
\hline 3MI0194 & GROUP A & 0 & 1 & 0 & 0 & 0 & 501 \\
\hline $3 \mathrm{MI0045}$ & GROUP B & 0 & 1 & 1 & 0 & 1 & $772 ; 345$ \\
\hline $3 \mathrm{MI0035}$ & GROUP B & 0 & 0 & 1 & 1 & 1 & 366 \\
\hline 3LA0084 & GROUP B & 0 & 0 & 1 & 1 & 1 & \\
\hline 3LA0091 & GROUP B & 0 & 1 & 1 & 1 & 1 & 1114 \\
\hline 3LA0087 & GROUP B & 0 & 1 & 1 & 0 & 1 & $867 ; 1114 ; 3235$ \\
\hline 3LA0246 & GROUP B & 0 & 1 & 1 & 0 & 0 & 1114 \\
\hline 3LA0245 & GROUP B & 0 & 1 & 1 & 0 & 0 & 1114 \\
\hline 3LA0302 & GROUP B & 0 & 1 & 1 & 0 & 1 & 3235 \\
\hline 3LA0185 & GROUP B & 0 & 1 & 1 & 0 & 0 & 1114 \\
\hline 3LA0181 & GROUP B & 0 & 1 & 1 & 0 & 0 & 1114 \\
\hline 3LA0180 & GROUP B & 0 & 1 & 1 & 0 & 0 & 1114 \\
\hline 3LA0089 & GROUP B & 0 & 1 & 1 & 0 & 0 & \\
\hline $3 \mathrm{MI0029}$ & GROUP B & 1 & 1 & 1 & 1 & 1 & 366 \\
\hline 3LA0035 & GROUP B & 0 & 1 & 1 & 1 & 0 & \\
\hline 3LA0306 & GROUP B & 0 & 1 & 1 & 0 & 0 & 3235 \\
\hline 3LA0182 & GROUP B & 0 & 1 & 1 & 0 & 0 & 1114 \\
\hline 3LA0001 & GROUP B & 1 & 1 & 1 & 1 & 1 & $224 ; 366 ; 424 ; 218 ; 867 ; 1114 ; 2180$ \\
\hline 3LA0334 & GROUP B & 0 & 1 & 1 & 0 & 0 & 3235 \\
\hline 3LA0126 & GROUP B & 0 & 0 & 0 & 0 & 1 & $903 ; 772$ \\
\hline 3LA0085 & GROUP B & 0 & 0 & 1 & 0 & 0 & \\
\hline 3LA0227 & GROUP B & 0 & 1 & 1 & 0 & 0 & 1114 \\
\hline $3 \mathrm{MI0046}$ & GROUP B & 0 & 0 & 1 & 1 & 1 & $345 ; 772$ \\
\hline 3LA0121 & GROUP B & 0 & 1 & 1 & 0 & 1 & $903 ; 772$ \\
\hline 3LA0127 & GROUP B & 0 & 1 & 1 & 0 & 1 & $903 ; 772$ \\
\hline 3LA0133 & GROUP B & 1 & 0 & 0 & 0 & 0 & \\
\hline
\end{tabular}


Table 1. Great Bend Study Area Sites and Associated Artifacts recorded in AMASDA. (cont.)

\begin{tabular}{|c|c|c|c|c|c|c|c|}
\hline Sites & Location & Mound & Lithic & Ceramic & \begin{tabular}{|c|} 
Human \\
Remains \\
\end{tabular} & Faunal & AMASDA \# \\
\hline 3LA0132 & GROUP B & 1 & 0 & 0 & 0 & 0 & \\
\hline 3LA0131 & GROUP B & 0 & 1 & 1 & 0 & 0 & 1114 \\
\hline 3LA0219 & GROUP B & 0 & 1 & 1 & 0 & 0 & 1114 \\
\hline 3LA0220 & GROUP B & 0 & 1 & 1 & 0 & 0 & 1114 \\
\hline 3LA0312 & GROUP B & 0 & 0 & 1 & 0 & 0 & 3235 \\
\hline 3LA0313 & GROUP B & 0 & 1 & 1 & 0 & 0 & 3235 \\
\hline 3LA0213 & GROUP B & 0 & 1 & 0 & 0 & 0 & 1114 \\
\hline 3LA0048 & GROUP B & 0 & 1 & 1 & 0 & 1 & 3235 \\
\hline 3LA0207 & GROUP B & 0 & 1 & 1 & 0 & 0 & $1114 ; 3235$ \\
\hline 3LA0214 & GROUP B & 0 & 1 & 1 & 0 & 0 & 1114 \\
\hline 3LA0208 & GROUP B & 0 & 1 & 1 & 0 & 0 & 1114 \\
\hline 3LA0215 & GROUP B & 0 & 1 & 1 & 0 & 0 & 1114 \\
\hline 3LA0218 & GROUP B & 0 & 1 & 1 & 0 & 0 & 1114 \\
\hline 3LA0217 & GROUP B & 0 & 1 & 1 & 0 & 0 & 1114 \\
\hline 3LA0209 & GROUP B & 0 & 1 & 1 & 0 & 0 & 1114 \\
\hline 3LA0210 & GROUP B & 0 & 1 & 1 & 0 & 0 & 1114 \\
\hline 3LA0211 & GROUP B & 0 & 1 & 1 & 0 & 0 & 1114 \\
\hline 3LA0136 & GROUP B & 0 & 1 & 1 & 0 & 0 & \\
\hline 3LA0041 & GROUP B & 0 & 1 & 0 & 0 & 0 & 1085 \\
\hline 3LA0135 & GROUP B & 0 & 1 & 1 & 0 & 1 & \\
\hline 3LA0221 & GROUP B & 0 & 1 & 1 & 0 & 0 & 1114 \\
\hline 3LA0015 & GROUP B & 1 & 1 & 1 & 1 & 0 & $1114 ; 3235$ \\
\hline 3LA0320 & GROUP B & 0 & 1 & 1 & 0 & 0 & 3235 \\
\hline 3LA0223 & GROUP B & 1 & 1 & 0 & 0 & 0 & 1114 \\
\hline 3LA0339 & GROUP B & 0 & 1 & 0 & 0 & 0 & 3235 \\
\hline $3 \mathrm{MI0040}$ & GROUP B & 0 & 1 & 1 & 0 & 1 & 772 \\
\hline 3LA0196 & GROUP B & 0 & 1 & 0 & 0 & 0 & 1114 \\
\hline 3LA0190 & GROUP B & 0 & 1 & 0 & 0 & 0 & 1114 \\
\hline 3LA0206 & GROUP B & 0 & 1 & 0 & 0 & 0 & 1114 \\
\hline 3LA0003 & GROUP B & 0 & 1 & 1 & 0 & 0 & 1114 \\
\hline 3LA0097 & GROUP B & 0 & 1 & 1 & 1 & 1 & $633 ; 889$ \\
\hline 3LA0347 & GROUP C & 0 & 0 & 0 & 0 & 0 & \\
\hline 3LA0191 & GROUP C & 0 & 1 & 1 & 0 & 0 & 501 \\
\hline 3LA0021 & GROUP C & 1 & 1 & 1 & 0 & 0 & 1114 \\
\hline 3LA0022 & GROUP C & 1 & 1 & 0 & 0 & 1 & \\
\hline 3LA0129 & GROUP C & 0 & 1 & 1 & 0 & 1 & \\
\hline 3LA0120 & GROUP C & 0 & 1 & 1 & 0 & 0 & \\
\hline 3LA0119 & GROUP C & 0 & 1 & 0 & 0 & 0 & \\
\hline 3LA0244 & GROUP C & 0 & 1 & 0 & 0 & 0 & 1114 \\
\hline 3LA0239 & GROUP C & 1 & 1 & 1 & 0 & 0 & 1114 \\
\hline 3LA0230 & GROUP C & 0 & 1 & 1 & 0 & 0 & 1114 \\
\hline 3LA0238 & GROUP C & 0 & 1 & 1 & 0 & 0 & 1114 \\
\hline 3LA0103 & GROUP C & 0 & 1 & 1 & 0 & 0 & \\
\hline 3LA0105 & GROUP C & 0 & 1 & 0 & 0 & 0 & \\
\hline 3LA0106 & GROUP C & 0 & 1 & 1 & 0 & 0 & \\
\hline 3LA0104 & GROUP C & 0 & 1 & 1 & 0 & 0 & \\
\hline 3LA0109 & GROUP C & 0 & 1 & 1 & 0 & 1 & \\
\hline 3LA0116 & GROUP C & 0 & 1 & 1 & 0 & 0 & 501 \\
\hline
\end{tabular}


Directly east of the Red River, a large group (Group B) of sites $(n=56)$ have been recorded along the current river channel (see Figure 1). Within this group are six recorded mound sites (3MI29, 3LA1, 3LA15, 3LA132, 3LA133, 3LA223). The largest of the mound sites is the Battle Mound (3LA1) site (McKinnon 2009, 2010a; also discussed below). Within Group B, lithic debris has been recorded at 86\% of the sites, ceramic sherds at $82 \%$ of the sites, and faunal remains at $28 \%$ of the sites (see Table 1). Human remains have been found at several sites within this group, as well. The abundance and fairly equal distribution of lithic and ceramic artifacts, and especially the frequency of human remains likely associated with community cemeteries (see Brown 1984:54; Perttula 1992:83; Story 1990:338-339), suggest that many of the sites in this group represent the domestic constituents of a Caddo village or community spread out along the Red River, similar to that represented in the dispersed community recorded on the Terán map (see also Schambach 1982; Trubowitz 1984).

Of interest and noteworthy to mention, is the absence of sites along the immediate west bank of the Red River. A simple explanation might be the destruction of sites over time by the meandering Red River. If so, why are we seeing destruction and absence of sites on the west side of the river, whereas so many are extant on the east side of the river?

Further east is a smaller cluster (Group C) of sites ( $\mathrm{n}=17)$ that are situated within the upland landscape, peering down, if you will, into the Red River floodplain (see Figure 1). Among this group are three mounds: Spirit Lake Farm Mound (3LA239), Red Hill Mound (3LA21), and Field Bayou Mound (3LA22). In addition to the multiple mound sites in Group C, lithic debris has been recorded at $94 \%$ of the sites, ceramic sherds at $71 \%$ of the sites, and faunal remains at $18 \%$ of the sites (see Table 1 ). Human remains have not been recorded at any of the Group C sites.

If these initial interpretations of landscape use and activity, as provisionally defined by the archaeological record, are applied to Caddo cosmological principles, some thoughts on the organization of space in the Great Bend region are offered. As Sabo (2012) has emphasized in his analysis of the Terán map and Caddo cosmology, the cardinal directions of east-west correspond to life and death symbolism. The east, with the rising sun, is associated with life-affirming events and rituals, such as renewal ceremonies, whereas the west, with the setting sun, is connected to life-threatening events and rituals, such as hunting and warfare.

Applying these cosmological principles to sites in the study area and considering the north-south meandering Red River as the central element (axis mundi?), might the "lithic-dominant" group of sites located west of the river (Group A) represent specific use or activity associated with life-threatening events, such as hunting? Looking east to the group of sites (Group C) situated along the uplands and the presence of lithics (food processing?), ceramics (large cooking vessels?), faunal remains (feasting?), and a concentration of mounds (ceremonial grounds?), might this group represent specific landscape use or activities associated with life-affirming ceremonial events, such as seasonal cooking and feasting ceremonies purposefully held along the uplands above and overlooking the river valley?

At this point, these are observations and thoughts based on spatial distribution and associated archaeological artifacts (many of which are location-biased as part of levee revetment projects). As such, these observations and thoughts will require further detailed analysis of each site, the artifacts, and intra-site distributional attributes. Nonetheless, these observations provide interesting considerations and a model to test toward exploring regional landscapes and the relationship of sites on a more humanistic perspective rather than simply looking at the regional landscape as clusters of sites. 


\section{An Intra-Site Ritual Landscape}

Applying the proposed model to a second resolution, that of the site or intra-site scale, considerations of similar regional-based Caddo cosmological principles can also be explored. To exemplify this, the Battle Mound site will be utilized as a case study - primarily because it is one of the few sites in the Great Bend region that has been recently examined in terms of distributions across the intra-site landscape (McKinnon 2009, 2010a). Additionally, as it relates to the location of sites within the Great Bend study area previously discussed, the site is centrally located within the three groups or clusters of sites situated across the Red River floodplain valley. Undoubtedly, Battle Mound certainly served as a center of population and social organization in the Great Bend region during the Middle and Late Caddo Period from at least A.D. 1200 (Schambach 1982). Radiocarbon dates from mound excavations at the site range from ca. AD 1390-1545 (McKinnon 2011b, 2012a; Valastro et al. 1972).

The most prominent feature at the Battle Mound site is a multi-level platform mound. The large mound is composed of at least three platform levels and a large slope on the eastern side of the mound. Orientation of the mound is north-south (parallel to the direction of the Red River) and directly east of the mound are two very low rises - although it is still unclear at this time if these low rises are deliberate constructions or created by natural riverine processes and subsequently utilized (probably both). It is known that they do contain archaeological features, identified as part of geophysical surveys conducted at the site.

To date, a total of 14.24 ha (35.19 acres) of magnetic gradiometry data have been collected at the site. The corpus of anomalies identified as a part of these surveys are interpreted as a total of at least 19 circular structures, 12 rectangular structures, a dense farmstead area, four possible compound fences, a likely community cemetery, and a buried borrow pit - all of which are interpreted as being Caddo in origin (McKinnon 2009, 2010a).

Additionally, in the early 1980s, a controlled surface collection was undertaken in 10 delineated areas (labeled A-J; see McKinnon 2010a:Figure 3) and those artifacts have recently been sorted and counted (Schambach et al. 1980; McKinnon 2010b). Several of the delineated surface collection areas overlap geophysical survey areas, allowing for more confident interpretations of the subsurface anomalies.

In examining the distribution of cultural features identified in geophysical survey, four areas are of particular interest. First, a survey area (Area C) located directly west of the mound contains very few geophysical anomalies, suggesting a lack of long-term structures or an area of lower activity or use. One of the geophysical anomalies in Area C, situated directly west of the large mound, is interpreted as a circular structure containing an extended entranceway (Figure 2). The proposed extended entranceway is facing east toward the mound. Surface collections in the area west of the mound substantiate considerations of a lower activity use area with a few amounts of daub $(n=29)$, ceramic sherds $(n=94)$, a small amount of lithic debris $(n=27)$, and a single faunal bone $(n=1)$ collected.

A second area (Area E), directly east of the large mound and situated on a low rise, contains numerous anomalies that form concentric circles of low magnetism, suggesting that these anomalies are the result of minimal or minor burning episodes (Figure 3a). Their concentric pattern is interesting in its own right, but why are so many structures clustered together with limited evidence of burning? Surface collections reveal fairly low numbers of daub ( $n=5)$, ceramics $(n=288)$, and lithics $(n=56)$ (Table 2), suggesting these might be community structures, rebuilt over time and lacking numerous vessels. When finally disposed, it is suggested that the structures in Area E were not subjected to high heat burning as a result of being partially dismantled 
prior to disposal. To compare, excavations on the south platform of the mound document a multiple floor structure (Structure 1) that was associated with community events (Howard 1948; Krieger 1949; McKinnon 2010c). Structure 1 had a construction sequence that consisted of a structural retrofit where the roof was removed and the building reconstructed without burning, which may have been directly related to a frequency of cooking activities in the structure (McKinnon 2012b).

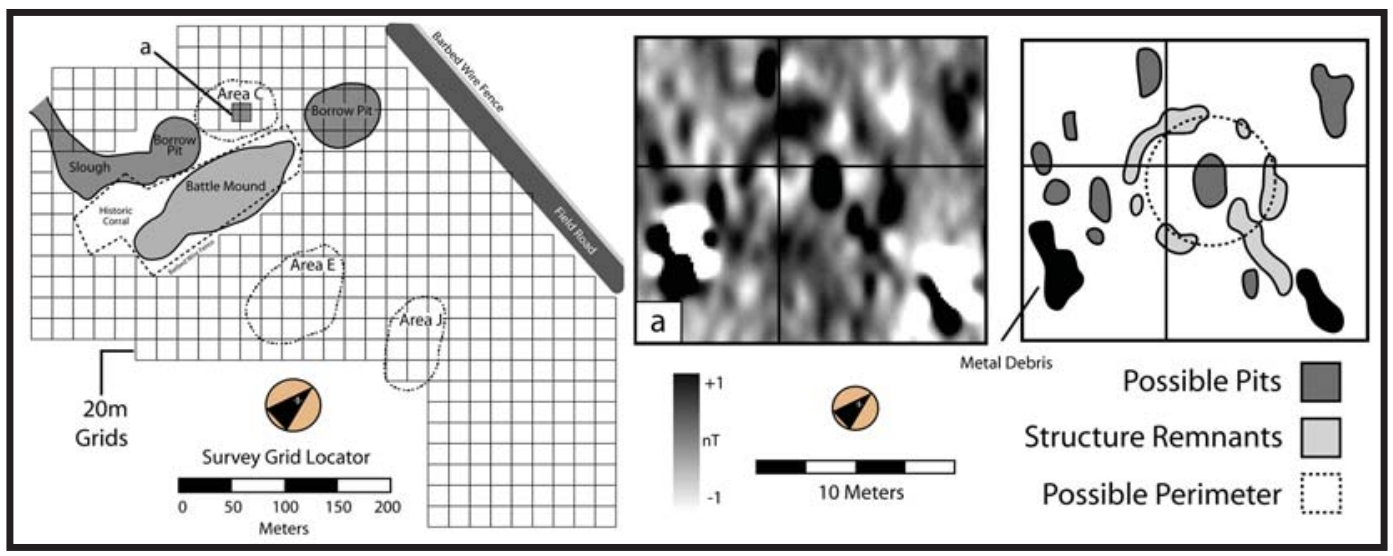

Figure 2. Geophysical results from Area C directly west of the large mound: (a) circular structure with extended entranceway.

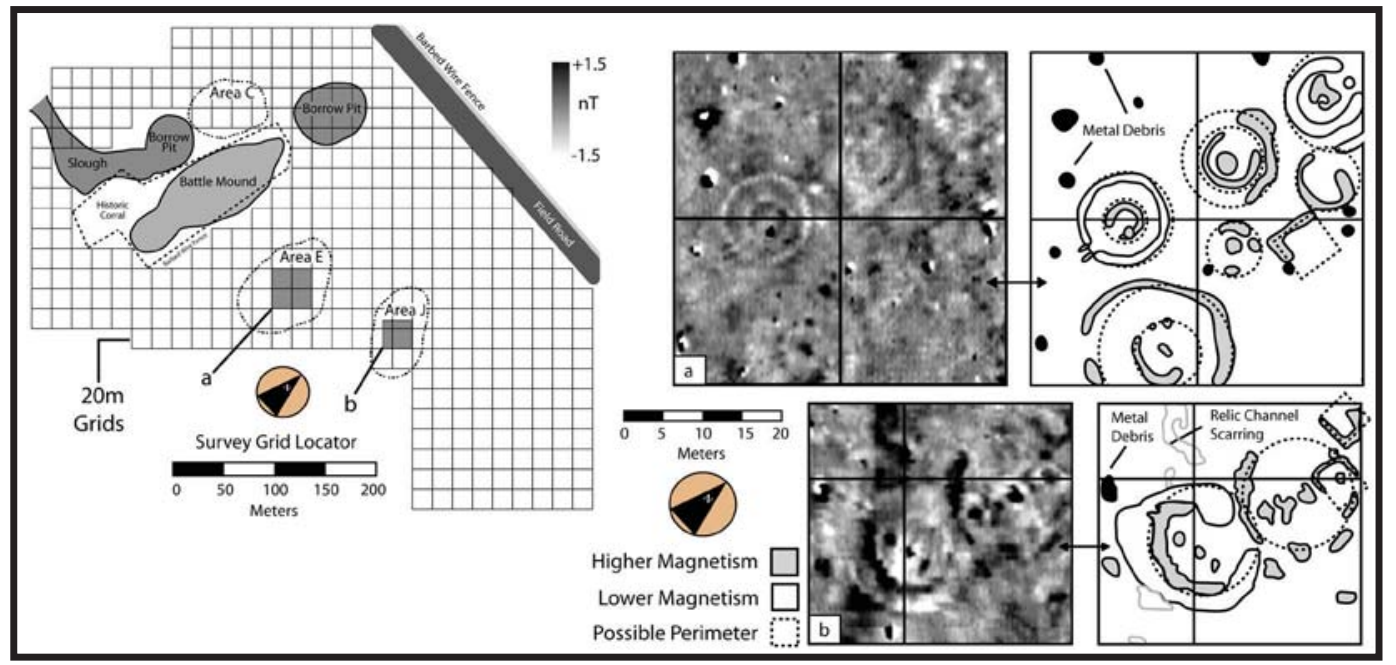

Figure 3. Geophysical results from Area E and Area J east of the large mound: (a) circular structures in Area E directly east of the mound on a low rise; (b) circular structures in Area J 200 m east of the mound on a separate low rise.

Table 2. Surface Collection Areas and Associated Counts of Collected Artifacts.

\begin{tabular}{|l|r|r|r|r|r|}
\hline \multicolumn{1}{|c|}{ Area } & \multicolumn{1}{c|}{ Ceramics } & \multicolumn{1}{c|}{ Lithics } & \multicolumn{1}{c|}{ Daub } & \multicolumn{1}{c|}{ Bone } & \multicolumn{1}{c|}{ Historic } \\
\hline A & 1446 & 474 & 16 & 40 & 70 \\
\hline B & 615 & 80 & 2 & 9 & 8 \\
\hline C & 94 & 27 & 29 & 3 & 5 \\
\hline D & 294 & 73 & 3 & 5 & 1 \\
\hline E & 288 & 56 & 5 & 0 & 2 \\
\hline F & 51 & 18 & 0 & 0 & 0 \\
\hline G & 536 & 151 & 3 & 3 & 5 \\
\hline H & 2102 & 215 & 150 & 47 & 5 \\
\hline I & 70 & 40 & 4 & 1 & 1 \\
\hline J & 89 & 80 & 13 & 2 & 0 \\
\hline
\end{tabular}


A third area (Area J), also on a low rise and a little further east, contains two large concentric circular anomalies and associated structural elements (Figure 3b). Magnetic readings are much higher in this area suggesting that these anomalies represent components of burned structures. Surface collections corroborate this suggestion with large chunks of daub $(n=13)$ collected in this area. However, counts of ceramic $(n=89)$ and lithic $(n=80)$ material collected from the surface are low in quantity. Similar to the structures in Area E, the Area J structures might also represent community structures that lack numerous vessels - the difference being that the large structures in Area J are defined by a different construction sequence where the entire structure was subjected to high heat burning events, rather than dismantled or only partially burned.

Lastly, about 20-meters east of Area J is an area that has been interpreted as a Caddo community cemetery (McKinnon 2009:Figure 6; Walker and McKinnon 2012:Figure 7-17). Investigations by Moore (1912:566-573) east of the large mound located five burials in a low rise. Additionally, numerous excavations in the 1930s and 1940s reported many burials in a cemetery east of the large mound (Lemley Collection Notes). Caddo community cemeteries have been noted to contain numerous individuals, the size of the cemeteries depending on settlement densities of the surrounding populations (Brown 1984:54; Perttula 1992:83; Story 1990:338-339). It is interesting to note that the large cemetery located at the Hatchel site, that is the site containing the temple mound depicted on the Terán map, was located east of the large mound (Perttula 2005).

As with the regional scale interpretations, the distribution of geophysical features at Battle Mound can be examined in terms of cosmological principles expressed across the landscape. Using the same simplified model - the east associated with life-affirming events and rituals and the west associated with life-threatening events and rituals - how might these be manifest at (and in) the Battle Mound landscape?

Foremost is the difference in quantity of anomalies between the east and west sides of the mound. If the north-south orientation of the large mound is considered the central element (axis mundi?) that bisects the site - much like the Red River bisecting the floodplain landscape - there is clearly a difference in the number of identified geophysical features between the east and west. West of the mound is sparse, with only five small structures interpreted (see McKinnon 2009:Figure 10; McKinnon 2010a:Figure 11). East of the mound is much more populous, with at least 15 structures interpreted. Many of them are quite large in dimension, suggesting communal or ceremonial use. Comparing the intra-site distribution to the regional scale distribution, might there be a similar relationship between the absence of sites directly west of the Red River and the low number of structures identified in geophysical data directly west of the mound? Could those structures on the west side of the mound be reserved for life-threatening events, such as processing areas for hunted game? If so, the area west of the mound would have certainly contained numerous temporary structures related to processing of meat and hides, such as drying racks - ephemeral architectural features that would be difficult to detect using geophysics.

Additionally, the abundance of structures east of the mound spatially correlates with the abundance of sites east of the Red River. Might these numerous and large structures east of the mound represent locales reserved for communal life-affirming ceremonies? The large size of the Area E and J circular anomalies, their interesting concentric-circle arrangement (see McKinnon 2009:252 for discussion on interpretations of concentric circle anomalies), surface collections containing low amounts of ceramic and lithic debris, and their orientation on two (the only two that can be seen today) low rises suggest structures related to communal or ceremonial activities. 
What about the possible community cemetery on the eastern periphery? Going out on an interpretive limb, might the location of the cemetery represent a reciprocal relationship between the Above World and the Below World? Individuals are interred on the life-affirming eastern edge of the community, to then travel to the Above World (a life-affirming renewal, if you will) toward the ancestral realm of the dead.

\section{Conclusion}

As the title of this paper states, these initial observations are thoughts. As presented here, they offer opportunity and direction for future investigations - a model - that can be tested and compared archaeologically and at multiple scales in an attempt to define various spatial components and the ideological meanings encoded within. Clearly, fieldwork with a focus of testing the proposed model and evaluation of artifact collections is necessary. In many cases, sites have only been identified as part of larger cultural resource projects where the extent of the site boundaries (defined in some cases only by a couple of shovel tests) is not understood.

Nonetheless, there should be no doubt that landscapes contain meanings - be they esoteric or commonplace. Our challenge as archaeologists is to use an interdisciplinary approach (ethnography, archaeology, ethnohistory, geography, and the like) when analyzing spatial data to provide insight into humanistic concepts of landscapes that have been deliberately arranged, organized, executed, and modified based upon a particular suite of highly integrated political, social, economic, and ideological rules and aspirations about space.

\section{Acknowledgements}

Thanks to Lela Donat, Registrar at the Arkansas Archeological Survey, for access to records located in the AMASDA database. Thanks to Dr. Frank Schambach, John Miller, and Dr. David Kelley for the surface collection efforts at the Battle Mound site (SAU17). Material gathered during surface collections has proved to be a valuable resource in the examination of off-mound distributions. An original version of this paper was presented as part of the symposium "Symbolic and Visual Communication in the Mississippian Period: Interpretation, Context, and Methodology" (F. Kent Reilly, III and Adam King, organizers) at the 67th Annual Meeting of the Southeastern Archaeological Conference, Lexington, Kentucky.

\section{References Cited}

Anschuetz, Kurt F., Richard H. Wilshusen, and Cherie L. Scheick

2001 An Archaeology of Landscapes: Perspectives and Directions. Journal of Archaeological Research 9:157-211.

Ashmore, Wendy, and A. Bernard Knapp (editors)

1999 Archaeologies of Landscape: Contemporary Perspectives. Blackwell, Oxford.

Bailey, Garrick (editor)

1995 The Osage and Invisible World: From the Works of Francis la Flesche. University of Oklahoma Pres.

Blitz, John H., and Lorenz, Karl G.

2006 The Chattahoochee Chiefdoms. University of Alabama Press, Tuscaloosa. 


\section{References Cited (cont.)}

Bolton, Herbert Eugene

1987 The Hasinais: Southern Caddoans as Seen by the Earliest Europeans. University of Oklahoma Press, Norman.

Brown, James A.

1976 The Southern Cult Reconsidered. Midcontinental Journal of Archaeology 1:115-136.

1984 Prehistoric Southern Ozark Marginality: A Myth Exposed. Special Publications No. 6. Missouri Archaeological Society, Columbia.

2012 Spiro Reconsidered: Sacred Economy at the Western Frontier of the Eastern Woodlands. In The Archaeology of the Caddo, edited by Timothy K. Perttula and Chester P. Walker, pp. 117-138. University of Nebraska Press.

Cobb, Charles R.

2003 Mississippian chiefdoms: How complex? Annual Review of Anthropology 32: 63-85.

Dalan, Rinita A., George R. Holley, William I. Woods, Harold W. Watters, Jr., and John A. Koepke 2003 Envisioning Cahokia: A Landscape Perspective. Northern Illinois University Press.

David, Bruno, and Julian Thomas (editors)

2008 Handbook of Landscape Archaeology. Left Coast Press.

Deetz, James F.

1982 Households: A Structural Key to Archaeological Explanation. American Behavioral Scientist 25:717724 .

Emerson, Thomas E.

1997 Cahokia and the Archaeology of Power. University of Alabama Press, Tuscaloosa.

Feld, Steven, and Keith H. Basso

1996 Senses of Place. School of American Research, Santa Fe.

Freidel, David A., and Linda Schele

1988 Kingship in the Late Preclassic Maya Lowlands: The Instruments and Places of Ritual Power. American Anthropologist 90:547-567.

Galloway, Patricia K. (editor)

1989 The Southeastern Ceremonial Complex: Artifacts and Analysis. University of Nebraska Press, Lincoln.

Gasco, Janine

1992 Documentary and Archaeological Evidence of Household Differentiation in Colonial Soconusco, New Spain. In Text-Aided Archaeology, edited by Barbara J. Little, pp. 83-96. CRC Press.

Girard, Jeffrey S.

2012 Settlement Patterns and Variation in Caddo Pottery Decoration: A Case Study of the Willow Chute Bayou Locality. In The Archaeology of the Caddo, edited by Timothy K. Perttula and Chester P. Walker, pp. 239-287. University of Nebraska Press. 


\section{References Cited (cont.)}

Gibson, Jon L.

2001 The Ancient Mounds of Poverty Point: Place of Rings. University Press of Florida.

Griffith, William

1954 The Hasinai Indians of East Texas as Seen by Europeans 1687-1772. Middle American Research Institute, Tulane University, New Orleans.

Hatcher, Mattie Austin

1932 The Expedition of Don Domingo Teran de los Rios into Texas (1691-1692). Preliminary Studies of the Texas Catholic Historical Society 2:3-62.

Hirsch, Eric, and Michael O'Hanlon

1995 The Anthropology of Landscape: Perspectives on Place and Space. Clarendon Press, Oxford.

Howard, James $\mathrm{H}$.

1968 The Southeastern Ceremonial Complex and its Interpretation. Memoir 6. Missouri Archaeological Society, Columbia.

Howard, Lynn H.

1948 Battle Mound Daily Log Notes. Notes on file, Arkansas Archeological Survey, Fayetteville, Arkansas.

Jackson, Edwin H., Susan L. Scott, and Frank F. Schambach

2012 At the House of the Priest: Faunal Remains from the Crenshaw Site (3MI6), Southwest Arkansas. In The Archaeology of the Caddo, edited by Timothy K. Perttula and Chester P. Walker, pp. 47-85. University of Nebraska Press.

Kay, Marvin, George Sabo III, Ralph Merletti

1989 Late Prehistoric Settlement Patterning: A View from Three Caddoan Civic-ceremonial Centers in Northwest Arkansas. In Contributions to Spiro Archaeology: Mound Excavations and Regional Perspectives, edited by Rogers, J.D., D. Wyckoff, D.A. Peterson. pp.129-157.0klahoma Archaeological Survey, Norman.

King, Adam, Chester P. Walker, Robert V. Sharp, F. Kent Reilly, III, and Duncan P. McKinnon

2011 Remote Sensing from Etowah's Mound A: Architecture and the Re-Creation of Mississippian Tradition. American Antiquity 75(2):355-371.

Kniffen, Fred B., Hiram F. Gregory, and George A. Stokes

1987 The Historic Indian Tribes of Louisiana From 1542 to the Present. Louisiana State University Press, Baton Rouge.

Knight, Vernon J. Jr.

1986 The Institutional Organization of Mississippian Religion. American Antiquity 51:675-687.

1998 Moundville as a Diagrammatic Ceremonial Center. In Archaeology of the Moundville Chiefdom, edited by Vernon James Knight, Jr., and Vincas P. Steponaitis, pp. 44-62. The University of Alabama Press, Tuscaloosa. 


\section{References Cited (cont.)}

Knight, Vernon J. Jr., James A. Brown, and George E. Lankford

2001 On the Subject Matter of Southeastern Ceremonial Complex Art. Southeastern Archaeology 20:129141.

Kornfeld, Marcel, and Alan J. Osborn (editors)

2003 Islands on the Plains: Ecological, Social, and Ritual Use of Landscapes. University of Utah Press.

Krieger, Alex, D.

1946 Culture Complexes and Chronology in Northern Texas, with Extensions of Puebloan Datings to the Mississippi Valley. Publication No. 4640. The University of Texas, Austin.

1949 Viking Fund Grant for Battle Mound Excavations, Lafayette County, Arkansas: A Reportof Activities and Expenditures as of January 31, 1949. Manuscript on file, Arkansas Archeological Survey, Fayetteville, Arkansas.

Lemley Collection Notes on the Battle Place. On file, Gilcrease Museum, Tulsa, Oklahoma.

Lepper, Bradley T.

2004 The Newark Earthworks: Monumental Geometry and Astronomy at a Hopewellian Pilgrimage Center In Hero, Hawk, and Open Hand, edited by Richard F. Townsend, pp. 73-84. Yale University Press.

Lockhart, Jami J.

2012 Spatial Patterns of Caddo Mounds Sites in the West Gulf Coastal Plain of Arkansas. In The Archaeology of the Caddo, edited by Timothy K. Perttula and Chester P. Walker, pp.313-334. University of Nebraska Press.

Low, Sarah, and Denise Lawrence-Zúñiga

2003 The Anthropology of Space and Place: Locating Culture. Blackwell Publishers.

Marrinan, Rochelle A., and White, Nancy Marie

2007 Modeling Fort Walton culture in northwest Florida. Southeastern Archaeology 26:292-318.

Matthews, Roger

2004 Landscapes of Terror and Control: Imperial Impacts in Paphlagonia. Near Eastern Archaeology 67:200-211.

McKinnon, Duncan P.

2009 Exploring Settlement Patterning at a Premier Caddo Mound Site in the Red River Great Bend Region. Southeastern Archaeology 28(2):248-258.

2010a Continuing the Research: Archaeogeophysical Investigations at the Battle Mound Site (3LA1) in Lafayette County, Arkansas. Manuscript on file, Arkansas Archeological Survey, Fayetteville, Arkansas. Southeastern Archaeology 29(2):250-260. 


\section{References Cited (cont.)}

McKinnon, Duncan P.

2010b From the Surface: An Analysis of Surface Collections from Battle Mound (3LA1), a Premier Caddo Mound Site in the Red River Great Bend Region. Paper presented at the 50th Annual Meeting of the Arkansas Archeological Society, Hot Springs, Arkansas.

2010c Summer 1948: A Summary of the Krieger Excavations at Battle Mound (3LA1), a Premier Caddo Mound Site in the Red River Great Bend Region. The Arkansas Archeologist 49:1-16.

2011a Foreword: A Review of Woodland and Caddo Archeology in Arkansas. In Archeology in Arkansas: Selected Articles from The Arkansas Archeologist, Bulletin of the Arkansas Archeological Society, Volume 1, Caddo Archaeology, assembled by Duncan P. McKinnon, pp. 5-24. Gustav's Library Publishing, Davenport, IA.

2011b Thirty Years in the Foil: An ARF-Funded AMS Date from Battle Mound (3LA1). Field Notes: Newsletter of the Arkansas Archeological Society 362:6-8.

2012a Corn Cobs Collected in 1948: An ARF-Funded AMS Date from Battle Mound (3LA1). Field Notes: Newsletter of the Arkansas Archeological Society 368:8-9.

2012b Dr. Krieger Comes To Arkansas: The 1948 Mound Excavations at Battle Mound (3LA1). Paper presented as part of the symposium "Current Research on Caddo Archeology" (Mary Beth Trubitt, organizer) at the 83th Annual Meeting of the Texas Archeological Society, Tyler, Texas.

Moore, Clarence. B.

1912 Some Aboriginal Sites on the Red River. Journal of Academy of Natural Sciences of Philadelphia, $14: 481-638$

Moran, Emilio F.

2008 Human Adaptability: An Introduction to Ecological Anthropology. Westview Press, Boulder.

Newcomb, W.W., Jr.

1961 The Indians of Texas from Prehistoric to Modern Times. University of Texas Press, Austin.

Olwig, Kenneth R.

2001 Landscape as a Contested Topos of Place, Community, and Self. In Textures of Place: Exploring Humanist Geographies, edited by Paul C. Adams, Steven Hoelscher, and Karen E. Till. University of Minnesota Press, London.

Perttula, Timothy K.

1992 "The Caddo Nation": Archaeological and Ethnohistoric Perspectives. University of Texas Press, Austin.

2005 1938-1939 WPA Excavations at the Hatchel Site (41BW3) on the Red River in Bowie, County, Texas. Southeastern Archaeology 24:180-198.

2009a Foreword: A Current Perspective on Caddo Archeology. In Classics in Texas Archeology: Selected Articles from the Early Years of the Bulletin of the Texas Archeological Society, Volume 1, Caddo Archeology, assembled by Timothy K. Perttula, pp. 5-18. Gustav's Library Publishing, Davenport, IA.

2009b Extended Entranceway Structures in the Caddo Archaeological Area. Southeastern Archaeology $29(1): 27-42$. 


\section{References Cited (cont.)}

Perttula, Timothy K.

2012a The Archaeology of the Caddo in Southwest Arkansas, Northwest Louisiana, Eastern Oklahoma, and East Texas: An Introduction to the Volume. In The Archaeology of the Caddo, edited by Timothy K. Perttula \& Chester P. Walker, pp. 1-25. University of Nebraska Press.

2012b A Caddo Archeology Map. Caddo Archeology Journal 22:17-20.

Perttula, Timothy K., and Robert Rogers

2007 The Evolution of a Caddo Community in Northeastern Texas: The Oak Hill Village Site (41RK214), Rusk County, Texas. American Antiquity 72(1):71-94.

Pluckhahn, Thomas J.

2010 Household Archaeology in the Southeastern United States: History, Trends, and Challenges. Journal of Archaeological Research 18:331-385.

Pollack, David

2004 Caborn-Welborn: Constructing a New Society after the Angel Chiefdom Collapse. University of Alabama Press, Tuscaloosa.

Rafferty, Janet R., and Peacock, Evan (editors)

2008 Time's River: Archaeological Syntheses from the Lower Mississippi River Valley. University of Alabama Press, Tuscaloosa.

Rees, Mark A., and Livingood, Patrick C. (editors)

2007 Plaquemine Archaeology. University of Alabama Press, Tuscaloosa.

Reilly, F. Kent, III

2004 People of Earth, People of Sky: Visualizing the Sacred in Native American Art of the Mississippian Period. In Hero, Hawk, and Open Hand: American Indian Art of the Ancient Midwest and South, edited by Richard F. Townsend, pp. 125-139. Yale University Press.

Robb, John G.

1998 The 'Ritual Landscape' Concept in Archaeology: A Heritage Construction. Landscape Research 23(2):159-175.

Sabo, George, III

1995 Encounters and Images: European Contact and the Caddo Indians. Historical Reflections/Reflexions Historiques 21:217-242.

2008 Rock Art and the Study of Ancient Religions in Southeastern North America. In R e l i g i o n, Archaeology, and the Material World, edited by Lars Fogelin, pp. 279-296. Occasional Paper No. 36. Center for Archaeological Investigations, Southern Illinois University, Carbondale.

2012 The Terán Map and Caddo Cosmology. In The Archaeology of the Caddo, edited by Timothy K. Perttula and Chester P. Walker, pp. 431-448. University of Nebraska Press.

Sabo, George, III, and Deborah Sabo (editors)

2005 Rock Art in Arkansas. Popular Series No. 5. Arkansas Archeological Survey, Fayetteville. 


\section{References Cited (cont.)}

Saunders, Joe W., Rolfe D. Mandel, Garth Sampson, Charles M. Allen, E. Thurman Allen, Daniel A. Bush, James K. Feathers, Kristen J. Gremillion, C.T. Hallmark, H. Edwin Jackson, Jay K. Johnson, Reca Jones, Roger T. Saucier, Gary L. Stringer, and Malcolm F. Vidrine

2005 Watson Brake, a Middle Archaic Mound Complex in Northeast Louisiana. American Antiquity 70:631-668.

Schambach, Frank F.

1982 The Archeology of the Great Bend Region in Arkansas. In Contributions to the Archeology of the Great Bend Region, edited by Frank F. Schambach and Frank Rackerby, pp. 1-11. Research Series No. 22. Arkansas Archeological Survey, Fayetteville.

1996 Mounds, Embankments, and Ceremonialism in the Trans-Mississippi South. In Mounds, Embankments, and Ceremonialism in the Midsouth, edited by Robert C. Mainfort and Richard Walling, pp. 36-43. Research Series No. 46. Arkansas Archeological Survey, Fayetteville.

Schambach, Frank. F., John Miller, and David B. Kelley

1980 Original unpublished field notes from Battle Mound (3LA1). Manuscript on file, Arkansas Archeological Survey, Fayetteville, Arkansas.

Story, Dee Ann

1990 Culture History of the Native Americans. In The Archeology and Bioarcheology of the Gulf Coastal Plain, by Dee Ann Story, Janice A. Guy, Martha D. Freeman, Jerome C. Rose, D. Gentry Steele, Ben W. Olive, and Karl J. Reinhard, pp. 163-366. 2 Vols. Research Series No. 38. Arkansas Archeological Survey, Fayetteville.

Swanton, John R.

1942 Source Material on the History and Ethnology of the Caddo Indians. Bulletin 132. Bureau of American Ethnology, Smithsonian Institution, Washington D.C.

Thompson, George F.

1995 Landscapes in America. University of Texas Press.

Trubitt, Mary Beth

2009 Burning and Burying Buildings: Exploring Variation in Caddo Architecture in Southwest Arkansas. Southeastern Archaeology 28(2):233-247.

Trubowitz, Neal L. (editor)

1984 Cedar Grove: An Interdisciplinary Investigation of a Late Caddo Farmstead in the Red River Valley. Research Series No. 23. Arkansas Archeological Survey, Fayetteville.

Valastro S., Jr., E. Mott Davis, and Alejandra G. Varela

1972 University of Texas At Austin Radiocarbon Dates IX. Radiocarbon 14(2): 461-485.

Vogel, Gregory

2012 Viewshed Characteristics of Caddo Mounds in the Arkansas Basin. In The Archaeology of the Caddo, edited by Timothy K. Perttula and Chester P. Walker, pp. 139-176. University of Nebraska Press. 


\section{References Cited (cont.)}

Walker, Chester P., and Duncan P. McKinnon

2012 Exploring Prehistoric Caddo Communities through Archaeogeophysics. In The Archaeology of the Caddo, edited by Timothy K. Perttula \& Chester P. Walker, pp. 177-208. University of Nebraska Press.

Walker, Chester, P., and Timothy K. Perttula

2007 Remote Sensing at the Horace Cabe Site (41BW14). Caddo Archeology Journal 16:37- 44.

Waring, Jr., Antonio J., and Preston Holder

1945 A Prehistoric Ceremonial Complex in the Southeastern United States. American Anthropologist 47(1):1-34.

Webb, Clarence $\mathrm{H}$.

1959 The Belcher Mound: A Stratified Caddoan Site in Caddo Parish, Louisiana. Society for American Archaeology 16.

Webb, Clarence H., and Hiram F. Gregory

1986 The Caddo Indians of Louisiana. 2nd Edition. Anthropological Study 2. Department of Culture, Recreation, and Tourism, Louisiana Archaeological Survey and Antiquities Commission, Baton Rouge.

Wedel, Mildred Mott

1978 La Harpe's 1719 Post on Red River and Nearby Caddo Settlements. The Texas Memorial Museum Bulletin 30.

Wilk, Richard R., and William L. Rathje

1982 Household Archaeology. American Behavioral Scientist 25:617-639.

Wilkinson, T. J.

2003 Archaeological Landscapes of the Near East. The University of Arizona Press, Tucson. 